\title{
Water sorption of resin-modified glass-ionomer cements photoactivated with LED
}

\section{Sorção de água de cimentos de ionômero de vidro modificados por resina fotoativados com LED}

\author{
Daniela Francisca Gigo Cefaly* \\ Linda Wang* \\ Liliam Lucia Carrara Paes de Mello** \\ Janaína Lima dos Santos*** \\ Jean Rodrigo dos Santos*** \\ José Roberto Pereira Lauris ${ }^{* * * *}$
}

\begin{abstract}
The Light Emitting Diodes (LED) technology has been used to photoactivate composite resins and there is a great number of published studies in this area. However, there are no studies regarding resin-modified glass-ionomer cements (RMGIC), which also need photoactivation. Therefore, the aim of this study was to evaluate water sorption of two RMGIC photoactivated with LED and to compare this property to that obtained with a halogen light curing unit. A resin composite was used as control. Five specimens of $15.0 \mathrm{~mm}$ in diameter $\mathrm{x} 1.0 \mathrm{~mm}$ in height were prepared for each combination of material (Fuji II LC Improved, Vitremer, and Filtek Z250) and curing unit (Radii and Optilight Plus) and transferred to desiccators until a constant mass was obtained. Then the specimens were immersed into deionized water for 7 days, weighed and reconditioned to a constant mass in desiccators. Water sorption was calculated based on weight and volume of specimens. The data were analyzed by two-way ANOVA and Tukey test $(p<0.05)$. Specimens photocured with LED presented significantly more water sorption than those photocured with halogen light. The RMGIC absorbed statistically significant more water than the resin composite. The type of light curing unit affected water sorption characteristics of the RMGIC.
\end{abstract}

DESCRIPTORS: Glass ionomer cements; Water; Light.

RESUMO: A tecnologia baseada em Diodos emissores de luz (LED) tem sido utilizada para a fotoativação de resinas compostas e existe um grande número de estudos publicados a este respeito. Entretanto, não existem estudos envolvendo cimentos de ionômero de vidro modificados por resina (CIVMR), que também necessitam fotoativação. Assim, o objetivo deste estudo foi o de avaliar a sorção de água de dois CIVMR fotoativados com LED e comparar essa propriedade com aquela obtida com unidade com lâmpada halógena. Uma resina composta foi utilizada como controle. Cinco espécimes com 15,0 mm diâmetro x 1,0 mm de altura foram preparados para cada combinação de material (Fuji II LC Improved, Vitremer e Filtek Z250) e fonte de luz (Radii e Optilight Plus) e transferidos a dessecadores até a obtenção de massa constante. Em seguida, os espécimes foram imersos em água deionizada por 7 dias, pesados e recondicionados a uma massa constante em dessecadores. A sorção de água foi calculada com base no peso e no volume dos espécimes. Os dados foram analisados por ANOVA a dois critérios e teste de Tukey $(\mathrm{p}<0,05)$. Os espécimes fotoativados com LED apresentaram maior sorção de água que os fotoativados com lâmpada halógena. Os CIVMR absorveram mais água que a resina composta. O tipo de unidade de fotoativação afetou as características de sorção de água dos CIVMR.

DESCRITORES: Cimentos de ionômeros de vidro; Água; Luz.

\section{INTRODUCTION}

Halogen lamps are the most frequently used sources for photoactivation of resin-based dental materials. Their benefits include low cost technology while their drawbacks involve the production of high temperatures and the decline of irradiance over time due to bulb and filter ageing. ${ }^{8,12}$ The development of Light Emitting Diodes (LED) curing units has overcome some disadvantages of halogen curing units. Its benefits include a narrow emission spectrum that falls closely within the absorption range

\footnotetext{
*Assistant Professors; **MSc Student; ***Undergraduate Students - Department of Operative Dentistry, North of Paraná University.

**** Professor, Department of Orthodontics, Pediatrics and Public Health, School of Dentistry of Bauru, University of São Paulo.
} 
Cefaly DFG, Wang L, Mello LLCP, Santos JL, Santos JR, Lauris JRP. Water sorption of resin-modified glass-ionomer cements photoactivated with LED. Braz Oral Res 2006;20(4):342-6.

of camphorquinone that initiates the polymerization of resin monomers. ${ }^{11}$ As a consequence, the light emitted by LED lamps is much more efficient.

Since the introduction of LED for photoativation of dental materials, some studies were proposed to investigate its influence on different properties of resin based materials. ${ }^{1,3,7}$ Recent researches have shown that resin composites photoactivated with LED curing units have even presented better properties than those photoactivated with halogen lamps. ${ }^{1,23}$ Most of the studies focus on resin composite properties. ${ }^{1,3,7}$ However, no studies were found regarding the effect of LED on resin-modified glass ionomer cements (RMGIC), which also need to be photoactivated.

A major concern about glass-ionomer cements is related to its susceptibility to water gain or loss, since water plays an important role in the cement setting. Water is responsible for the transport of calcium and aluminum cations, which will react with the polyacid to form a polyacrylate matrix. ${ }^{26}$ If water is lost, due to desiccation, the reactions may stop and surface crazing may occur. ${ }^{10,26}$ On the other hand, early moisture contamination results in loss of substance as well as reduction of physical properties and loss of translucency. ${ }^{16,18}$

The development of RMGIC resulted in materials with improved mechanical properties ${ }^{9,24}$ and reduced early moisture sensitivity ${ }^{9,26}$ However, these materials take up more water than conventional ionomers due to their 2-hydroxyethylmethacrylate (HEMA) content that is hydrophilic. ${ }^{13,29}$ Studies have shown a correlation between the decrease in the physical properties of RMGICs and the water uptake. ${ }^{2,20}$

Based on the concerns mentioned above, the aim of this study was to evaluate the water sorption of resin-modified glass-ionomer cements photoactivated with LED or halogen lamps.

\section{MATERIAL AND METHODS}

Two resin-modified glass-ionomer cements and one composite resin (control) were tested. Table 1 lists the materials used in this study. Shade A3 was used for all materials.

Water sorption test was based on ISO 4049:2000 5 and previous works that used the same methodology. ${ }^{13,27,29}$ The powder and liquid of glass ionomers were weighed and, after mixing, the materials were injected by syringe (Centrix Incorporated, Shelton, CT, USA) into stainless steel moulds. The resin composite was inserted into the mould with a stainless steel spatula. The moulds (15.0 $\mathrm{mm}$ in diameter and $1.0 \mathrm{~mm}$ in height) were slightly over-filled with the materials. A piece of film was placed onto the material in the mould and covered with a glass slide. Hand pressure was applied for 20 seconds while excess material was extruded from the top of the mould.

The specimens were then light-cured by two curing units: Radii (SDI, Bayswater, Victoria, Australia) (Light Emitting Diodes - LED) and Optilight Plus (Gnatus, Ribeirão Preto, SP, Brazil) (Halogen lamp - HAL) for the recommended exposure time through a glass plate. Five specimens of each material were prepared for each curing unit. Power-densities of curing units were $600 \mathrm{mWcm}^{-2}$ and $400 \mathrm{mWcm}^{-2}$ for Radii and Optilight Plus, respectively. Power-densities were measured by means of a radiometer (Curing radiometer, Model 100P/N-150503 - Demetron Research Corp., Danbury, CT, USA). Due to the large area of the specimens, overlapping irradiation was essential. The specimens were ejected from the moulds and stored in a desiccator maintained at $37 \pm 1^{\circ} \mathrm{C}$. After 22 hours, the specimens were transferred to

TABLE 1 - Characteristics of the materials.

\begin{tabular}{c|l|l|l|c}
\hline \hline Code & \multicolumn{1}{|c|}{$\begin{array}{c}\text { Material } \\
\text { (manufacturer) }\end{array}$} & \multicolumn{1}{c}{ Type } & \multicolumn{1}{c}{ Main components } \\
\hline F & $\begin{array}{l}\text { Fuji II LC Improved } \\
\text { GC América INC, Alsip, } \\
\text { IL, USA) }\end{array}$ & $\begin{array}{l}\text { Resin-modified } \\
\text { glass-ionomer } \\
\text { cement }\end{array}$ & $\begin{array}{l}\text { Liquid: Polyacrylic acid 20-25\%, 2- } \\
\text { Hydroxyethyl Methacrylate 30-35\% } \\
\text { Proprietary Ingredient 5-15\%, 2,2,4, Trimethyl } \\
\text { hexamethylene dicarbonate TMHMD 1-5\%. } \\
\text { Powder: Alumino-silicate glass 95-100\% }\end{array}$ & 0305071 \\
V & $\begin{array}{l}\text { Vitremer } \\
\text { (3M ESPE Products, St. } \\
\text { Paul, MN, USA) }\end{array}$ & $\begin{array}{l}\text { Resin-modified } \\
\text { glass-ionomer } \\
\text { cement }\end{array}$ & $\begin{array}{l}\text { Powder: fluoro-aluminosilicate glass, } \\
\text { potassium persulfate, ascorbic acid. Liquid: } \\
\text { 50\% polyacrylic acid copolymer, 20\% HEMA, } \\
\text { water, 13\% carboxylic acid copolymer }\end{array}$ & 20030114 \\
\hline$Z$ & $\begin{array}{l}\text { Filtek Z250 (3M ESPE } \\
\text { Products, } \\
\text { St. Paul, MN, USA) }\end{array}$ & $\begin{array}{l}\text { Composite } \\
\text { resin }\end{array}$ & $\begin{array}{l}\text { Organic matrix: BIS-GMA, UEDMA, BIS-EMA. } \\
\text { Inorganic filler: 60\% by volume zirconia/ silica }\end{array}$ & 4FT \\
\hline \hline
\end{tabular}


Cefaly DFG, Wang L, Mello LLCP, Santos JL, Santos JR, Lauris JRP. Water sorption of resin-modified glass-ionomer cements photoactivated with LED. Braz Oral Res 2006;20(4):342-6.

a desiccator maintained at $23 \pm 1^{\circ} \mathrm{C}$ for 2 hours and weighed on an analytical balance $(0.1 \mathrm{mg}$ resolution) (Bel Engineering SRL, Mark 205A, Monza, MI, Italy). This cycle was repeated until a constant mass was obtained. The specimens were immersed into deionized water and maintained at $37^{\circ} \mathrm{C}$ for 7 days. After this period, the specimens were removed, washed with water, dried with absorbent paper, waved in air for $15 \mathrm{~s}$ and weighed 1 minute after removal from water $\left(\mathrm{M}_{1}\right)$. After this weighing, the specimens were reconditioned to constant mass $\left(\mathrm{M}_{2}\right)$ in desiccators using the cycle described before. The diameter and thickness of the specimens at the centre of the specimen and at four equally spaced points on the circumference were measured. The volume (V) of each specimen was calculated in cubic millimeters. The water sorption $\left(\mathrm{W}_{\mathrm{Sp}}\right)$ was determined using the following equation: $\mathrm{W}_{\mathrm{Sp}}=\left(\mathrm{M}_{1}-\mathrm{M}_{2}\right) / \mathrm{V}$. Values were expressed in $\mu \mathrm{g} / \mathrm{mm}^{3}$.

\section{RESULTS}

Statistical analyses were performed using the software Statistica for Windows version 5.1 (StatSoft Inc., Tulsa, USA). Two-way ANOVA showed that there was statistically significant difference among materials $(\mathrm{F}=6560.35 ; \mathrm{p}<0.001)$ and between curing units $(F=7.09 ; p=0.014)$. There was no significant interaction between factors $(\mathrm{F}=0.19 ; \mathrm{p}=0.824)$.

Specimens photocured with LED presented statistically significant more water sorption than those photocured with halogen curing unit.

Tukey test was used for multiple comparisons between materials. RMGIC sorbed statistically significant more water than the resin composite $(p<0.05)$. Vitremer sorbed statistically significant more water than Fuji II LC ( $p<0.05)$.

The mean values and the standard deviation of the water sorption are shown in Table 2.

TABLE 2 - Mean sorption of the tested materials.

\begin{tabular}{l|c}
\hline \hline \multicolumn{1}{c|}{ Material/Curing unit } & $\begin{array}{c}\text { Water sorption in } \mu g / \\
\mathrm{mm}^{3} \text { (standard deviation) }\end{array}$ \\
\hline Fuji II LC Improved/LED & $157.92(6.22)$ \\
\hline Fuji II LC Improved/HAL & $152.37(5.33)$ \\
\hline Vitremer/LED & $174.91(5.39)$ \\
\hline Vitremer/HAL & $169.53(7.47)$ \\
\hline Z250/LED & $26.91(1.32)$ \\
\hline Z250/HAL & $25.51(1.21)$ \\
\hline \hline
\end{tabular}

\section{DISCUSSION}

The present study showed that specimens photocured with LED presented significantly more water sorption than those photocured with the halogen curing unit. It may be explained by the relationship between cross-link density and water sorption. Composites with lower cross-link densities may be more prone to hydrolysis and water sorption, leading to less than optimal material properties and reduced clinical longevity. ${ }^{4,28}$ When a cross-linkable polymerization reaction starts, the initial stages develop a more linear polymer. Only during the late stages of conversion, when the physical distance between cross-linkable components has become small, does the greatest extent of cross-linking occur. The rapid development of network viscosity may result in shorter chains of lower molecular weight with less cross-linking. ${ }^{19}$ Most of the energy produced by LED falls within the absorption spectrum of camphorquinone photoinitiators, resulting in a greater efficiency of LED than that of the halogen lamp ${ }^{15}$. In addition, the power-density of the tested LED curing unit is higher than that of the halogen curing unit. Consequently, polymerization with LED might have occurred faster than with the halogen light.

The aforementioned may be responsible for the lower cross-link density of materials polymerized with LED than with halogen light and for the consequent greater water sorption of specimens cured with LED. Yap et al. ${ }^{30}$ (2004) also concluded that composites cured with LED may be less cross-linked than those cured with conventional halogen lights.

Although not informed in the data sheet of the materials, it is supposed that the photoinitiator of polymerization present in the studied RMGIC might be camphorquinone. It is an important consideration because it was demonstrated that LED curing units did not polymerize composites containing co-initiators to the same extent as did the halogen curing unit. ${ }^{22}$

All materials sorbed water. The RMGIC sorbed statistically significant more water than the resin composite. ${ }^{13,29}$ It occurred because the HEMA present in the liquid of the RMGIC is hydrophilic in nature, and materials with a higher HEMA content have consequently higher water sorption. ${ }^{13,29}$ Vitremer showed statistically significant more water sorption than Fuji II LC Improved. Although Fuji II LC Improved has more HEMA (30-35\%) (Fuji II LC Improved data sheet) than Vitremer (20\%), ${ }^{17}$ the powder:liquid ratio of Fuji II LC $(3.2: 1.0 \mathrm{~g})$ is 
Cefaly DFG, Wang L, Mello LLCP, Santos JL, Santos JR, Lauris JRP. Water sorption of resin-modified glass-ionomer cements photoactivated with LED. Braz Oral Res 2006;20(4):342-6.

$28 \%$ higher than that of Vitremer (2.5:1 g). Considering the powder:liquid ratio, Vitremer has more liquid and consequently more HEMA than Fuji II LC Improved.

Although water sorption is a characteristic of resin-based materials, it has been demonstrated that it adversely affects the mechanical properties of the RMGIC, particularly by decreasing flexural strength, flexural elastic modulus and hardness. ${ }^{2}$ In addition, water sorption leads to color changes in fillings. ${ }^{6}$ Therefore, the higher sorption of specimens cured with LED than with halogen lamp may negatively interfere with mechanical and esthetic properties of RMGIC restorations.

Considering methodology, composite resin was used as control group because studies have shown that LED units produce resin specimens with similar properties to those obtained with halogen units. ${ }^{1,21,23}$ Although RMGIC set without photoactivation due to an acid/base reaction and a self-

\section{REFERENCES}

1. Bala O, Olmez A, Kalayci S. Effect of LED and halogen light curing on polymerization of resin-based composites. J Oral Rehabil. 2005;32(2):134-40.

2. Cattani-Lorente MA, Dupuis V, Payan J, Moya F, Meyer JM. Effect of water on the physical properties of resin-modified glass-ionomer cements. Dent Mater. 1999;15(1):71-8.

3. Dunn WJ, Bush AC. A comparison of polymerization by light-emitting diode and halogen-based light-curing units. J Am Dent Assoc. 2002;133(3):335-41.

4. Indrani DJ, Cook WD, Televantos F, Tyas MJ, Harcourt JK. Fracture toughness of water-aged resin composite restorative materials. Dent Mater. 1995;11(3):201-7.

5. International Organization for Standardization. Dentistry polymer-based filling, restorative and luting materials. ISO 4049:2000. Geneva: ISO; 2000.

6. Iwami Y, Yamamoto H, Sato W, Kawai K, Torii M, Ebisu S. Weight change of various light-cured restorative materials after water immersion. Oper Dent. 1998;23(3):132-7.

7. Jandt KD, Mills RW, Blackwell GB, Ashworth SH. Depth of cure and compressive strength of dental composites cured with blue light emitting diodes (LEDs). Dent Mater. 2000;16(1):41-7.

8. Martin FE. A survey of the efficiency of visible light curing units. J Dent. 1998;26(3):239-43.

9. Mathis RS, Ferracane JL. Properties of a glass-ionomer/resin-composite hybrid material. Dent Mater. 1989;5(5):3558.

10. McLean JW. Clinical applications of glass-ionomer cements. Oper Dent. 1992;5:184-90.

11. Mills RW, Jandt KD, Ashworth SH. Dental composite depth of cure with halogen and blue light emitting diode technology. Br Dent J. 1999;186(8):388-91.

12. Miyazaki M, Hattori T, Ichiishi Y, Kondo M, Onose H, Moore BK. Evaluation of curing units used in private dental offices. Oper Dent. 1998;23(2):50-4. cure of the resin phase, ${ }^{25}$ a control group without photoactivation was not tested. The reason is that it was demonstrated that irradiated specimens of RMGIC were $50 \%$ stronger than specimens that were allowed to cure in darkness. ${ }^{14}$

\section{CONCLUSION}

The water sorption of specimens photoactivated with LED was higher than that of specimens photoactivated with a halogen curing unit. The effect of the higher water sorption on the mechanical properties and the clinical performance of RMGIC photoactivated with LED need future investigations.

\section{ACKNOWLEDGEMENTS}

The authors are grateful to Veralúcia Santos for her assistance at the laboratory.

13. Mortier E, Gerdolle DA, Jacquot B, Panighi MM. Importance of water sorption and solubility studies for couple bonding agent - resin-based filling material. Oper Dent. 2004;29(6):669-76.

14. Mount GJ, Patel C, Makinson OF. Resin modified glass-ionomers: strength, cure depth and translucency. Aust Dent J. 2002;47(4):339-43.

15. Nomoto R. Effect of light wavelength on polymerization of light-cured resins. Dent Mater J. 1997;16(1):60-73.

16. Oilo G. Early erosion of dental cements. Scand J Dent Res. 1984;92(6):539-43.

17. Pereira PNR, Sano H, Ogata M, Zheng L, Nakajima $\mathrm{M}$, Tagami $\mathrm{J}$ et al. Effect of region and dentin perfusion on bond strengths of resin-modified glass ionomer cements. J Dent. 2000;28(5):347-54.

18. Phillips S, Bishop BM. An in vitro study of the effect of moisture on glass ionomer cement. Quintessence Int. 1985;16(2):175-7.

19. Rueggeberg F. Contemporary issues in photocuring. Compend Contin Educ Dent Suppl. 1999;25:S4-15; quiz S73.

20. Small ICB, Watson TF, Chadwick AV, Sidhu SK. Water sorption in resin-modified glass-ionomer cements: an in vitro comparison with other materials. Biomaterials. 1998;19(6):545-50.

21. Tolosa MCCG, Paulillo LAMS, Giannini M, Santos AJS, Dias CTS. Influence of composite restorative materials and light-curing units on diametrical tensile strength. Braz Oral Res. 2005;19(2):123-6.

22. Uhl A, Mills RW, Jandt KD. Photoinitiator dependent composite depth of cure and Knoop hardness with halogen and LED light curing units. Biomaterials. 2003;24(10):178795.

23. Uhl A, Sigusch BW, Jandt KD. Second generation LEDs for the polymerization of oral biomaterials. Dent Mater. 2004;20(1):80-7. 
Cefaly DFG, Wang L, Mello LLCP, Santos JL, Santos JR, Lauris JRP. Water sorption of resin-modified glass-ionomer cements photoactivated with LED. Braz Oral Res 2006;20(4):342-6.

24. Uno S, Finger WJ, Fritz U. Long-term mechanical characteristics of resin-modified glass ionomer restorative materials. Dent Mater. 1996;12(1):64-9.

25. Wilson AD. Resin-modified glass-ionomer cements. Int J Prosthodont. 1990;3(5):425-9.

26. Wilson AD, McLean JW. Glass-ionomer cement. Chicago: Quintessence; 1988.

27. Yap A, Lee CM. Water sorption and solubility of resin-modified polyalkenoate cements. J Oral Rehabil. 1997;24(4):310-4.
28. Yap AU, Teoh SH, Tan KB. Influence of water exposure on three-body wear of composite restoratives. J Biomed Mater Res. 2000;53(5):547-53.

29. Yap AUJ. Resin-modified glass ionomer cements: a comparison of water sorption characteristics. Biomaterials. 1996;17(19):1897-900.

30. Yap AUJ, Soh MS, Han VTS, Siow KS. Influence of curing lights and modes on cross-link density of dental composites. Oper Dent. 2004;29(4):410-5.

Received for publication on Dec 06, 2005

Sent for alterations on Apr 05, 2006

Accepted for publication on Sep 05, 2006 